\title{
Lipomas as an Extremely Rare Cause for Brachial Plexus Compression: A Case Series and Systematic Review
}

\author{
Oliver Gembruch ${ }^{1}$ Y Yahya Ahmadipour ${ }^{1} \quad$ Mehdi Chihi $^{1} \quad$ Thiemo F. Dinger $^{1} \quad$ Laurèl Rauschenbach $^{1}$ \\ Daniela Pierscianek $^{1} \quad$ Ramazan Jabbarli $^{1} \quad$ Ulrich Sure ${ }^{1} \quad$ Karsten H. Wrede $^{1}$ Anne-Kathrin Uerschels ${ }^{1}$ \\ ${ }^{1}$ Department of Neurosurgery, University Hospital Essen, University \\ of Duisburg-Essen, Essen, Germany \\ Address for correspondence Oliver Gembruch, MD, Department of \\ Neurosurgery, University Hospital Essen, Hufelandstrasse 55, \\ 45122 Essen, Germany (e-mail: oliver.gembruch@uk-essen.de).
}

J Brachial Plex Peripher Nerve Inj 2021;16:e10-e16.

\begin{abstract}
Keywords

- brachial plexus

- lipoma

- surgery

- intraoperative

- monitoring

Introduction Brachial plexus lipomas are extremely rare benign tumors that may cause slow progression of neurological deficits leading to thoracic outlet syndrome. Up to now, surgery remains challenging. The aim of this study is to present our surgical treatment regime and long-term neurological outcome in three cases of giant brachial plexus lipomas and to show results of systematic review.

Patients and Methods Retrospective analysis of our database "peripheral nerve lesion" to identify patients suffering from brachial plexus lipomas between January 1 , 2012, and December 31, 2019. Systematic review was performed for literature published until March 31, 2020, analyzing PubMed, Google Scholar, Scopus, and the Cochrane Collaboration Library independently by two authors.

Results Over the past years, three patients suffering from giant brachial plexus lipomas attended to our neurosurgical department. All patients underwent preoperative magnetic resonance imaging (MRI), ultrasound examinations, and electrophysiological testing. Tumors were removed microsurgically via anterior/posterior, supraclavicular/infraclavicular, and combined approaches. The patients were accessed postoperatively by MRI and clinical follow-up. Systematic review of the literature revealed 22 cases, which were analyzed in regard to demographics, surgical treatment, and neurological outcome.

Conclusion Brachial plexus lipomas are an extremely rare cause for brachial plexus compression. Total microsurgical removal with intraoperative electrophysiological monitoring is the treatment of choice with excellent long-term MRI and clinical outcome.
\end{abstract}

\section{Introduction}

Brachial plexus tumors are relatively rare, and treatment is often challenging due to the complex anatomical location with adjacent nervous and vascular structures. In the majority of the cases, lipomas are benign asymptomatic soft tissue

received

May 2, 2020

accepted after revision

July 26, 2020
DOI https://doi.org/

10.1055/s-0041-1726087.

ISSN 1749-7221. tumors showing only slow progression. Nevertheless, in very rare cases, deep-seated lipomas can grow to gigantic size measuring more than $10 \mathrm{~cm}$ of length ${ }^{1}$ before causing symptoms such as nerve compression-associated motor deficits, sensory alterations, pain, or visceral symptoms. ${ }^{2}$ The brachial plexus compression can lead thoracic outlet syndrome

\section{(c) 2021. The Author(s).}

This is an open access article published by Thieme under the terms of the Creative Commons Attribution License, permitting unrestricted use, distribution, and reproduction so long as the original work is properly cited. (https://creativecommons.org/licenses/by/4.0/)

Georg Thieme Verlag KG, Rüdigerstraße 14, 70469 Stuttgart, Germany 
(TOS)-like symptoms in some cases. A diverse group of disorders related to extrinsic compression of neurovascular structures between the first rib and the clavicle can cause TOS. Congenital and acquired etiologies such as bony anomalies (cervical ribs, transverse mega-apophyses, first rib abnormalities, and clavicle nonunions), soft tissue anomalies (cervical muscles hypertrophy or fibrous bands), and posture problems such as drooping or sagging of the shoulders or poor posture due to large breast are reported causes for TOS. ${ }^{3}$ Common symptoms are shoulder or upper limb pain, weakness, paresthesia, and impalpable radial pulse (Raynaud's phenomenon). Surgical treatment of those lesions is often challenging due to the distorted anatomy caused by the tumor. Additionally, tumor removal and even biopsy are accompanied by risk of neurological deficits. Furthermore, total tumor resection should be performed to avoid further neurological deficits related to growth of tumor remnants. ${ }^{4}$

This report presents our microsurgical treatment regime of brachial plexus lipomas with intraoperative electrophysiological monitoring and ultrasound assistance. Furthermore, systematic review was performed.

\section{Patients and Methods}

Retrospective analysis of our database "peripheral nerve lesion" revealed three cases of large brachial plexus lipomas all causing neurogenic TOS (nTOS). We analyzed medical records and preoperative/postoperative magnetic resonance imaging (MRI) and performed follow-up examinations to evaluate the long-term outcome.

The study was approved by the Institutional Review Board (Medical Faculty, University of Duisburg-Essen, Registration number: 18-7955-BO).

\section{Systematic Review of the Literature}

Systematic review was performed for literature published until March 31, 2020, analyzing PubMed, Google Scholar, Scopus, and the Cochrane Collaboration Library independently by two authors. Search keywords comprised "lipoma," "brachial plexus, brachial plexus neuropathies or brachial plexus neuropathy." Inclusion criteria were articles published in English presenting the clinical course, peripheral nerve location, and the treatment regime.

Furthermore, the reference lists of included articles were reviewed to identify and include additional eligible articles. Those studies were meticulously cross-referenced to ensure that patients were not included in multiple articles (- Fig. $\mathbf{1}$ ). The systematic review was conducted following Preferred Reporting Items for Systematic Reviews and Meta-Analyses guidelines. $^{5}$

\section{Results}

\section{Case 1}

A 62-year-old male patient presented with a pectoral subcutaneous mass lesion. The tumor showed progressive and visible growth over a period of more than 7 years, finally causing atrophy and a severe paresis of the triceps brachii

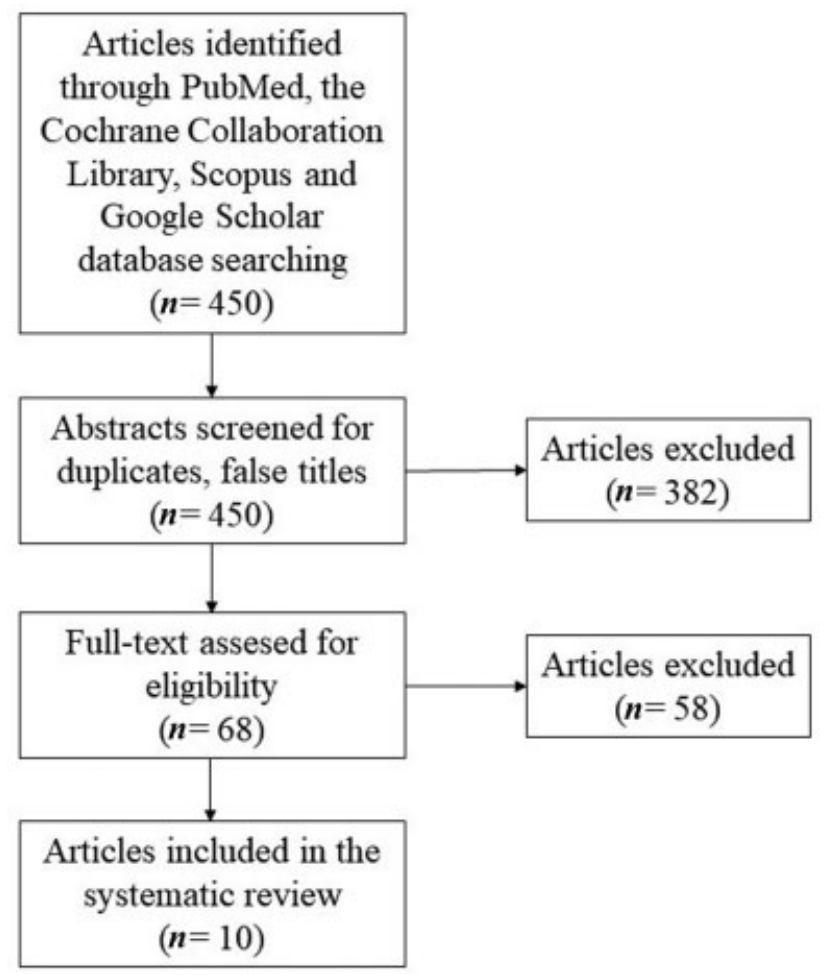

Fig. 1 Flowchart of the systematic review.

muscle, the biceps brachii muscle, the deltoid muscle, and the supraspinatus muscle. Electrophysiological testing revealed an impairment of the left brachial plexus and MRI showed a large lipomatous tumor extending from the area of the triceps brachii muscle toward the supraspinatus muscle, the clavicle, and the brachial plexus on the left side $(8 \times 7$ $\times 6 \mathrm{~cm}$ ). Total piecemeal tumor resection via a two-portal supraclavicular and infraclavicular approach and neurolysis finally led to a slight improvement of the paresis on the follow-up examination 12 months after surgery (-Fig. 2).

\section{Case 2}

A 61-year-old male patient presented with a 10-year history of right-sided TOS causing hypoesthesia of digitus IV and $\mathrm{V}$, a severe paresis of the triceps brachii muscle, the biceps brachii muscle, and the dorsal and palmar interossei muscles. Ultrasound and MRI of the neck depicted a large lipomatous mass $(10 \times 7 \times 5 \mathrm{~cm})$ compressing the right brachial plexus. Electrophysiological testing showed impairment of the axillary nerve. Total tumor resection via a dorsal suprascapular, infraclavicular approach and neurolysis finally led to improvement of the hypoesthesia 4 weeks after surgery. The severe paresis did not improve until the first neurological follow-up 15 months after surgery (-Fig. 3).

\section{Case 3}

A 56-year-old female patient presented with a progressive swelling of the left neck and shoulder over a period of around 2 years. Preoperative MRI revealed a left-sided brachial plexus lipoma with contact to the brachial plexus. Total tumor resection finally led to long-term relief of the 

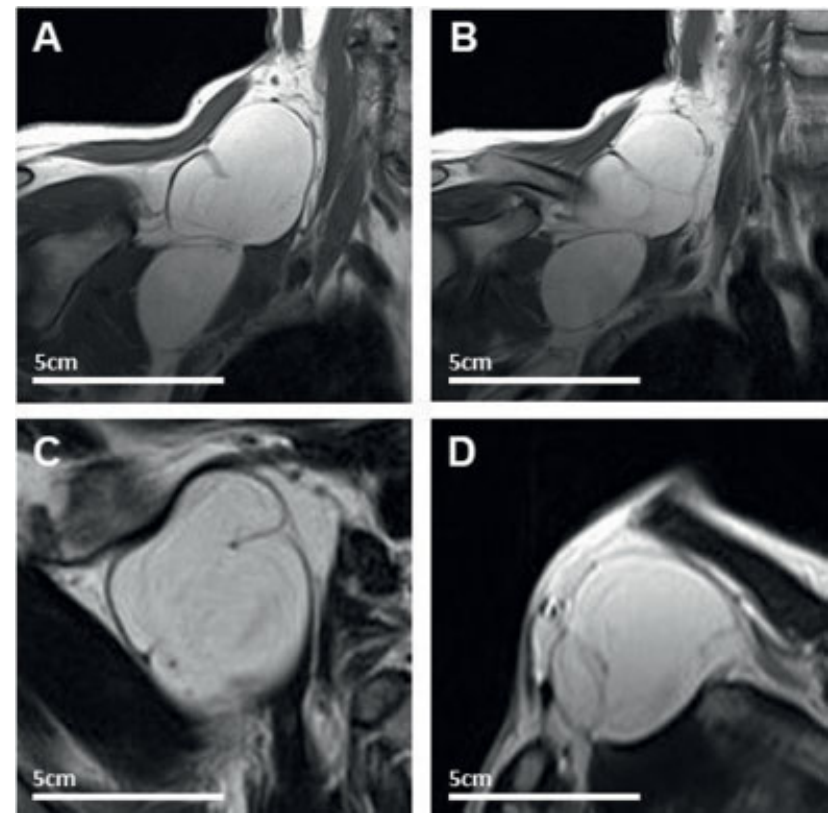

Fig. 2 T1-weigthed imaging showing the right brachial plexus lipoma $(12 \times 5 \mathrm{~cm})$. Coronal view (A, B), axial view (C), and sagittal view (D) of the lipoma.

symptoms. Follow-up examination 9 months after surgery revealed no neurological deficit.

\section{Surgery}

The patient was positioned in supine position and ultrasonography showed the supra- and infraclavicular lipomas under the pectoral muscle. Skin incision along the pectoral muscle to the axilla was followed by subcutaneous preparation toward the fascia of the muscle. Further preparation in the infraclavicular fossa visualized the lipoma beneath the clavicula. The capsule of the lipoma was then mobilized microsurgically. Further preparation was achieved via a second skin incision above the clavicula. Bipolar electrical stimulation (microfork probe $45 \mathrm{~mm}$ straight, Inomed, Emmendingen, Germany) was performed at the medial parts of the lipoma to test each nerve structure proximally and distally with voltages from 2 to $5 \mathrm{~mA}$ showing a vivid motor response. Mobilization of the tumor capsule was followed by piecemeal removal of the lipoma toward the brachial plexus using the Sonoca 300 (Söring GmBH, Quickborn, Germany) after nerve stimulation. A hemostasis procedure and subsequent removal of the lesion were followed, using bipolar coagulation. At the end, total tumor resection was achieved, and electrophysiological nerve stimulation showed that the displaced brachial plexus was not harmed (-Fig. 4).

\section{Results of the Systematic Review}

Database search revealed 450 articles. Total 382 articles were excluded after analyzing the title and the abstract. The full text of the remaining 68 articles was reviewed and 58 articles were excluded afterward. In total, 10 articles were included, ${ }^{2,6-14}$ comprising 22 cases of brachial plexus lipoma. Including our three cases, demographics, surgical treatment, and the neurological outcome were analyzed for 25
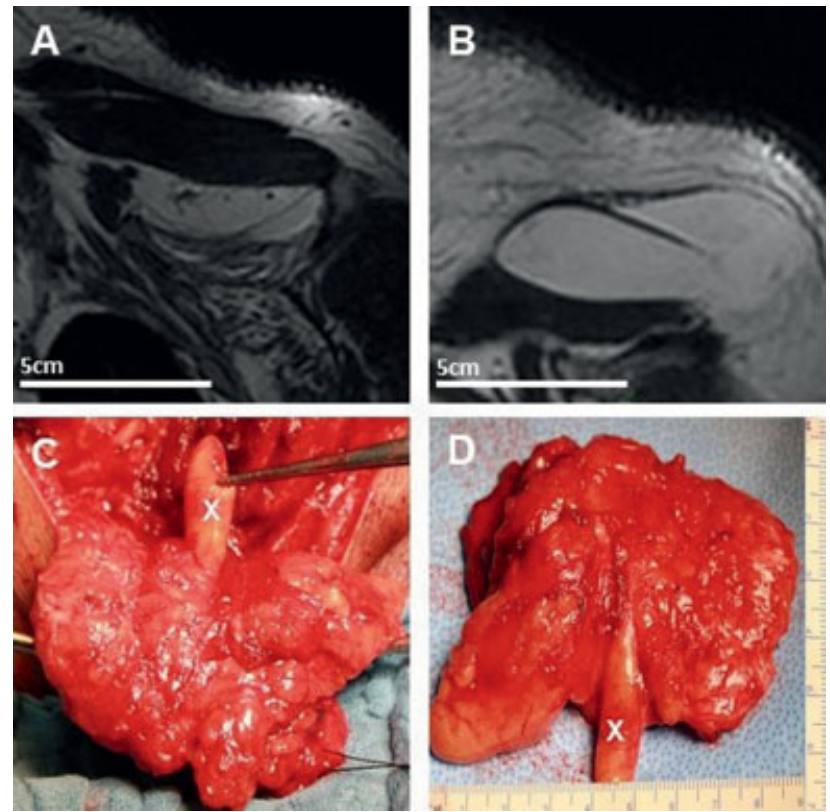

Fig. 3 Left-sided brachial plexus lipoma $(7 \times 9 \mathrm{~cm})$ on T2-weighted fat saturated magnetic resonance imaging $(A, B)$ and intraoperative view showing a "finger-like" growth of the lipoma (C, D).

patients (15 males and 10 females with mean age of $46.7 \pm 15.3$ years). Symptom duration was $32.5 \pm 39.5$ months. Presenting symptoms were sensory deficit in 13 patients, an enlarged mass in 9 patients, while 8 patients complained of radiating pain. Paresis was present in five patients. Symptoms were multiple in 10 patients. In all cases, complete resection of the lipoma was possible. Neurological outcome was unchanged in one patient and improved in three patients. Five patients were asymptomatic pre- and postoperatively, and the complete relief of the symptoms was
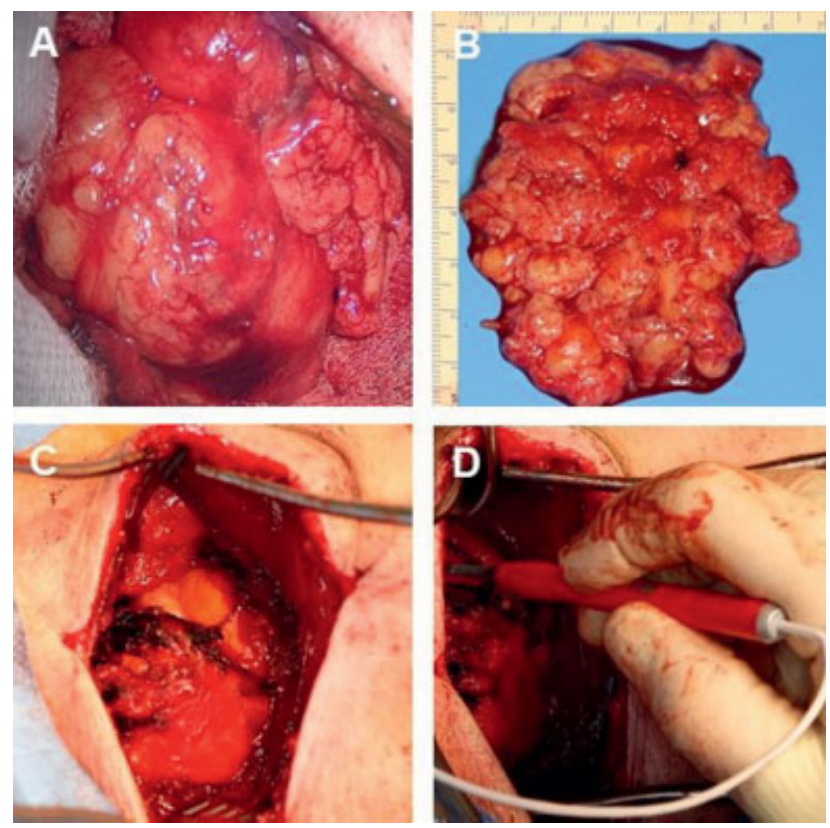

Fig. 4 Intraoperative view on the brachial plexus lipoma

$(7.5 \times 6.5 \mathrm{~cm}, \mathrm{~A}, \mathrm{C})$ and after removal $(\mathrm{B})$, intraoperative stimulation of the brachial plexus (D). 
seen in 13 cases at last follow-up (mean follow-up: $15.6 \pm 19.8$ months). Recurrence was detected in none of the 16 reported cases. However, in three included cases, reexcision was performed due to incomplete resection in another surgical center and continuing tumor growth (-Table 1).

\section{Discussion}

Three variants (venous, arterial, and neurological) of TOS have been described depending on the underlying pathophysiology. ${ }^{4}$ The heterogeneity of the symptoms related to this condition makes its diagnosis challenging and treatment is still controversial. ${ }^{15}$ The incidence is estimated to be 1 to $2 \%{ }^{16}$ with a female-to-male ratio of up to $4: 1 .^{17}$ However, nTOS generally affects the brachial plexus, representing $95 \%$ of overall TOS occurrences. ${ }^{18}$ Rinehardt et al analyzed the surgical treatment of TOS between 2005 and 2014 using the dataset of the American College of Surgeons National Surgical Quality Improvement Program. They identified 1,431 patients treated surgically (83\% for nTOS, $3 \%$ for arterial TOS and $12 \%$ for venous TOS, and subtype not identifiable in $2 \%)$. Surgery was performed in 1,286 cases by a vascular surgeon, in 100 cases by a general surgeon, in 38 cases by a thoracic surgeon, in 3 cases by a neurosurgeon, in 2 cases by an orthopaedic surgeon, and in 1 case by a cardiac surgeon and a plastic surgeon. ${ }^{19}$ Peek et al showed, in their systematic review of the literature, a 28.3-point improvement of the preoperative Disabilities of the Arm, Shoulder, and Hand score in nTOS and an overall improvement of symptoms in 56 to $89 \%$. Complication rates ranged between 5 and $40 \%$, with pneumothorax, nerve injuries, and wound infections being the most common complications. ${ }^{20}$

An extremely rare cause for nTOS is large lipoma adjacent to the brachial plexus, usually presenting as a subcutaneous mass and upper limb or shoulder pain. Lipomas are benign, slow-growing soft tissue tumors and the most common mesenchymal tumor with an estimated incidence of $10 \% .{ }^{21}$ This is supported by our systematic review of the literature, showing that $40.9 \%$ of the cases were detected due to its growth as a palpable mass and $59.1 \%$ of the patients reported only sensory deficits. Symptom duration varied between 2 months and 10 years. Slow growth pattern of that benign tumor and a slow onset on neurological deficits may be the reason for late diagnosis. Furthermore, adoption of the slow deterioration of neurological deficits and therefore delayed appointment to a physician was detected in our presented cases. Additionally, delayed transfer to a neurologist performing electrophysiological diagnostic or delayed MRI may be reasonable for prolonged diagnosis.

They can arise adipose tissue in any part of the body. Lipomas are commonly located in the back, thigh, forearm, chest, and the posterior neck ${ }^{22,23}$ and are usually solitary lesions. They present at multiple sites in 5 to $10 \%$ or rarely as a diffuse lipomatosis in a multisystem syndrome. ${ }^{24}$ Sanchez et al defined giant lipomas as lesions more than $10 \mathrm{~cm}$ in size or more than $1,000 \mathrm{~g}$ weight. ${ }^{1}$ The presence in various internal organs, such as liver, kidney, and lung, is also reported, although there is no or very little adipose tissue. Rarely, giant lipomas can cause pain and nerve compression syndromes. ${ }^{23}$ The pathophysiology of tumor growth in lipomas remains unclear. Traumata seem to have an impact on the pathogenesis of lipoma. The axillary region is one of the most moveable areas of the body and microtraumata can occur with each movement of the upper limb. ${ }^{25}$ Some authors propose that the proliferation of adipose tissue is caused by the rupture of the fibrous septa with a resulting migration of adipocytes, accompanied by tears of the anchorage between the skin and the deep fascia. ${ }^{26}$ An alternative theory is that lipomas are resulting from preadipocyte differentiation and proliferation mediated by cytokine release followed by soft tissue damage after blunt trauma and hematoma formation. ${ }^{25,27}$ Several histologically distinct subtypes have been described: lipoblastomas (immature vs. mature adipocytes), hibernoma (brown fat vs. white fat), angiolipoma (microvascular thrombosis present), spindle cell lipoma (mature fat cells with spindle cells and strands of dense collagen), and pleomorphic lipoma ("floret-like cells" present). ${ }^{24}$ Differential diagnoses of giant lipomas include lipoblastomas and liposarcomas. Liposarcomas are the most common soft tissue sarcomas and account for 7 to $27 \%$ of all soft tissue sarcomas. ${ }^{28}$ It is impossible to distinguish between lipomas and liposarcomas by the clinical appearance alone. Therefore, it is mandatory to rule out malignancy by surgical biopsy. Sarcomatous transformations of giant lipomas have been reported, but they are extremely rare. ${ }^{22}$ Malignant transformation was not reported in the included cases of the systematic review.

Lipomas should be differentiated from other brachial plexus tumors. Most common benign brachial plexus tumors are schwannomas and neurofibromas. ${ }^{29}$ Schwannomas are well encapsulated and characteristically form an eccentric oval swelling. The fascicles of the nerve are spread over its surface. ${ }^{30}$ They are normally hyperintense on T2-weighted MRI with cystic formations with a strong uniform contrast enhancement. Contrary to that, neurofibromas present a circular growth pattern. The fascicles are going through the tumor. On T2-weighted MRI, neurofibromas are iso- to hyperintense with a strong partial inhomogeneous contrast enhancement. $^{31}$

Nonoperative and surgical approaches have been described as therapy of TOS. ${ }^{3}$ Conservative treatment including physical therapy mainly focuses on strengthening and stretching of shoulder girdle elevator and pectoral muscles. ${ }^{32}$ Even though conservative treatment may be effective in patients with posture problems, it remains ineffective in cases with structural anomalies as it can, at best, delay surgery. ${ }^{3}$ Lipomas usually have a well-defined fibrous capsule and normally they can be resected easily by dissection around the lesions. ${ }^{22}$ In some cases, they can be squeezed out through short incisions. ${ }^{33}$ Liposuction of the lipoma through tiny incisions is performed by some authors even in cases of large lesions. ${ }^{34,35}$ Possible complications of liposuction are hematomas, or in cases of incomplete resection, recurrence of the lipoma. ${ }^{34}$ In our review, recurrence was not reported in none of the 16 reported cases, but 3 patients (12\%) had to 
e14 Brachia Plexus Lipomas Gembruch et al.

Table 1 Published cases of brachial plexus lipoma

\begin{tabular}{|c|c|c|c|c|c|c|c|c|c|}
\hline Year & Reference & Age & Sex & Presentation & $\begin{array}{l}\text { Symptom } \\
\text { duration }\end{array}$ & Therapy & $\begin{array}{l}\text { Postoperative out- } \\
\text { come }\end{array}$ & Follow-up & Recurrence \\
\hline 2003 & Sergeant et al ${ }^{12}$ & 70 & $\mathrm{M}$ & $\begin{array}{l}\text { High subpectoral pain, } \\
\text { irradiating to the left } \\
\text { upper arm and shoul- } \\
\text { der, paresthesia, epi- } \\
\text { sodic dullness of all left } \\
\text { fingers and a feeling of } \\
\text { heaviness and minor } \\
\text { swelling of the com- } \\
\text { plete left arm }\end{array}$ & $4 y$ & $\begin{array}{l}\text { Complete } \\
\text { resection }\end{array}$ & Complete relief & $5 w k$ & No \\
\hline 2005 & $\begin{array}{l}\text { Vandeweyer } \\
\text { and Scagnol }^{14}\end{array}$ & 62 & $\mathrm{~F}$ & Enlarging mass & $6 y$ & $\begin{array}{l}\text { Complete } \\
\text { resection }\end{array}$ & Asymptomatic & $1 \mathrm{y}$ & No \\
\hline 2007 & Châtillon et $\mathrm{al}^{6}$ & 44 & $\mathrm{~F}$ & $\begin{array}{l}\text { Right upper extremity } \\
\text { dysesthesias and pares- } \\
\text { thesia radiating from } \\
\text { the shoulder to the in- } \\
\text { dex and middle fingers }\end{array}$ & $\mathrm{nm}$ & $\begin{array}{l}\text { Complete } \\
\text { resection }\end{array}$ & Complete relief & $3 y$ & No \\
\hline 2009 & McKay et al ${ }^{11}$ & 31 & $\mathrm{M}$ & $\begin{array}{l}\text { Increasing shoulder } \\
\text { pain and right forearm } \\
\text { paresthesia }\end{array}$ & $1 \mathrm{y}$ & $\begin{array}{l}\text { Complete } \\
\text { resection }\end{array}$ & $\begin{array}{l}\text { Complete relief, but } \\
\text { mild residual right } \\
\text { eye ptosis }\end{array}$ & $1 \mathrm{mo}$ & No \\
\hline 2011 & Guha et $\mathrm{al}^{9}$ & 25 & $\mathrm{M}$ & $\begin{array}{l}\text { Pain and noticeable } \\
\text { weakness in the right } \\
\text { arm }\end{array}$ & $1 \mathrm{y}$ & $\begin{array}{l}\text { Complete } \\
\text { resection }\end{array}$ & Complete relief & $\mathrm{nm}$ & $\mathrm{nm}$ \\
\hline \multirow[t]{4}{*}{2014} & \multirow[t]{2}{*}{$\begin{array}{l}\text { Kuyumdzhiev } \\
\text { et } \mathrm{al}^{10}\end{array}$} & 64 & $\mathrm{~F}$ & $\begin{array}{l}\text { Numbness and tingling } \\
\text { in the right hand and } \\
\text { fingers with generalized } \\
\text { weakness }\end{array}$ & $3 \mathrm{mo}$ & $\begin{array}{l}\text { Complete } \\
\text { resection }\end{array}$ & Complete relief & $3 \mathrm{mo}$ & No \\
\hline & & 39 & $\mathrm{M}$ & $\begin{array}{l}\text { Altered sensation in the } \\
\text { medial aspect of the } \\
\text { right arm with pins and } \\
\text { needles in the ulnar } \\
\text { nerve distribution af- } \\
\text { fecting right hand }\end{array}$ & $\mathrm{nm}$ & $\begin{array}{l}\text { Complete } \\
\text { resection }\end{array}$ & $\begin{array}{l}\text { Alleviation of sen- } \\
\text { sory deficit }\end{array}$ & $5 \mathrm{mo}$ & No \\
\hline & \multirow[t]{2}{*}{ Nakamura et al ${ }^{2}$} & 47 & $\mathrm{M}$ & Enlarging mass & $4 \mathrm{mo}$ & $\begin{array}{l}\text { Complete } \\
\text { resection }\end{array}$ & Asymptomatic & $6 y$ & No \\
\hline & & 42 & $\mathrm{~F}$ & $\begin{array}{l}\text { Tenderness in the left } \\
\text { shoulder and numbness } \\
\text { in the lateral left upper } \\
\text { arm }\end{array}$ & $2 \mathrm{mo}$ & $\begin{array}{l}\text { Complete } \\
\text { resection }\end{array}$ & Complete relief & $28 \mathrm{mo}$ & No \\
\hline 2015 & Elia et $\mathrm{al}^{7}$ & 30 & $\mathrm{~F}$ & $\begin{array}{l}\text { Subpectoral and shoul- } \\
\text { der pain, right arm } \\
\text { swelling, right forearm } \\
\text { paresthesia }\end{array}$ & $6 \mathrm{mo}$ & $\begin{array}{l}\text { Complete } \\
\text { resection }\end{array}$ & Asymptomatic & $6 \mathrm{mo}$ & No \\
\hline \multirow[t]{11}{*}{2019} & \multirow[t]{11}{*}{ Graf et al ${ }^{8}$} & 58 & $M$ & Shoulder paresthesia & $\mathrm{nm}$ & Mass excision & Complete relief & $\mathrm{nm}$ & $\mathrm{nm}$ \\
\hline & & 64 & $\mathrm{~F}$ & $\begin{array}{l}\text { Left shoulder paresthe- } \\
\text { sia and hand intrinsic } \\
\text { weakness }\end{array}$ & $\mathrm{nm}$ & Excision & Complete relief & $\mathrm{nm}$ & $\mathrm{nm}$ \\
\hline & & 49 & $\mathrm{M}$ & Enlarging mass & $\mathrm{nm}$ & Excision & Asymptomatic & $\mathrm{nm}$ & $\mathrm{nm}$ \\
\hline & & 50 & $\mathrm{M}$ & Enlarging mass & $\mathrm{nm}$ & Reexcision & Asymptomatic & $\mathrm{nm}$ & No \\
\hline & & 26 & $\mathrm{~F}$ & $\begin{array}{l}\text { Shoulder numbness } \\
\text { and pain }\end{array}$ & $\mathrm{nm}$ & Excision & $\mathrm{Nm}$ & $\mathrm{nm}$ & $\mathrm{nm}$ \\
\hline & & 52 & $\mathrm{~F}$ & $\begin{array}{l}\text { Shoulder paresthesia, } \\
\text { enlarging mass }\end{array}$ & $\mathrm{nm}$ & Excision & Complete relief & $\mathrm{nm}$ & $\mathrm{nm}$ \\
\hline & & 45 & $\mathrm{M}$ & Enlarging mass & $\mathrm{nm}$ & Excision & $\mathrm{Nm}$ & $\mathrm{nm}$ & $\mathrm{nm}$ \\
\hline & & 30 & $\mathrm{M}$ & Painful enlarging mass & $\mathrm{nm}$ & Excision & Complete relief & $\mathrm{nm}$ & $\mathrm{nm}$ \\
\hline & & 24 & $\mathrm{~F}$ & $\begin{array}{l}\text { Recurrent shoulder } \\
\text { pain, recurrent enlarg- } \\
\text { ing masses }\end{array}$ & $\mathrm{nm}$ & Reexcision & Unchanged & $\mathrm{nm}$ & No \\
\hline & & 61 & $\mathrm{M}$ & Enlarging masses & $\mathrm{nm}$ & Excision & $\mathrm{Nm}$ & $\mathrm{nm}$ & $\mathrm{nm}$ \\
\hline & & 80 & M & Recurrent pain in axilla & $\mathrm{nm}$ & Reexcision & Complete relief & $\mathrm{nm}$ & No \\
\hline \multirow[t]{2}{*}{2019} & Sul et $\mathrm{al}^{13}$ & 45 & $\mathrm{M}$ & $\begin{array}{l}\text { Paresthesia and tingling } \\
\text { sensation of the left } \\
\text { arm }\end{array}$ & $3 \mathrm{mo}$ & $\begin{array}{l}\text { Complete } \\
\text { resection }\end{array}$ & Complete relief & $1 \mathrm{y}$ & No \\
\hline & Case 1 & 62 & M & $\begin{array}{l}\text { Causing atrophy and a } \\
\text { severe paresis of the } \\
\text { triceps brachii muscle, } \\
\text { the biceps brachii }\end{array}$ & $7 y$ & $\begin{array}{l}\text { Complete } \\
\text { resection }\end{array}$ & $\begin{array}{l}\text { Slight improvement } \\
\text { of the paresis }\end{array}$ & $12 \mathrm{mo}$ & No \\
\hline
\end{tabular}


Table 1 (Continued)

\begin{tabular}{|c|c|c|c|c|c|c|c|c|c|}
\hline Year & Reference & Age & Sex & Presentation & $\begin{array}{l}\text { Symptom } \\
\text { duration }\end{array}$ & Therapy & $\begin{array}{l}\text { Postoperative out- } \\
\text { come }\end{array}$ & Follow-up & Recurrence \\
\hline & & & & $\begin{array}{l}\text { muscle, the deltoid } \\
\text { muscle and the supra- } \\
\text { spinatus muscle }\end{array}$ & & & & & \\
\hline & Case 2 & 61 & M & $\begin{array}{l}\text { Hypoesthesia of digitus } \\
\text { IV and V, a severe pa- } \\
\text { resis of the triceps bra- } \\
\text { chii muscle, the biceps } \\
\text { brachii muscle and the } \\
\text { dorsal and palmar } \\
\text { interossei muscles }\end{array}$ & $10 \mathrm{y}$ & $\begin{array}{l}\text { Complete } \\
\text { resection }\end{array}$ & $\begin{array}{l}\text { Improvement of } \\
\text { hypoesthesia }\end{array}$ & $15 \mathrm{mo}$ & No \\
\hline & Case 3 & 56 & $\mathrm{~F}$ & $\begin{array}{l}\text { Progressive swelling of } \\
\text { the left neck and } \\
\text { shoulder }\end{array}$ & $2 y$ & $\begin{array}{l}\text { Complete } \\
\text { resection }\end{array}$ & Complete relief & $9 \mathrm{mo}$ & No \\
\hline
\end{tabular}

Abbreviations: MRI, magnetic resonance imaging; nm, not mentioned; nTOS, neurogenic thoracic outlet syndrome; TOS, thoracic outlet syndrome.

undergo re-excision after incomplete removal. Some authors favor a minimal invasive endoscopic approach via a small skin incision to remove the lipoma in total to avoid long skin incisions. ${ }^{36}$ In our opinion, a computed tomography-guided biopsy of the lipoma should not be performed. It carries the risk to displace tumor cells after violating the capsule of the lipoma. Furthermore, complete tumor removal leads to a decompression of the brachial plexus and to a relief of the symptoms.

Lipomas adjacent to major nerves and vessels should be removed by microsurgical excision with electrophysiological neuromonitoring to prevent neurological deficits. Blind aspiration may injure these structures, resulting in a major bleeding or neuromuscular dysfunction with paralysis.

Although advances in surgical strategies including peripheral nerve microsurgery have improved the outcome, there is still a risk of causing intraoperative damage. Preserving the neurological function while trying to achieve gross total resection should be the principle treatment goal. Therefore, intraoperative neurophysiological monitoring combined with intraoperative high-resolution ultrasound represents an effective technique for identifying and monitoring functional integrity of both the spinal cord and the nerve roots in real time. The benefit of intraoperative neurophysiological monitoring for preserving neuronal structures and achieving an optimal postoperative functional outcome was proven in several studies. ${ }^{37,38}$ Furthermore, electrophysiological monitoring is a useful tool to test nerve integrity and to determine the topography of the injury site. ${ }^{39}$

In our opinion, microsurgical resection with intraoperative electrophysiological monitoring should be performed to remove the tumor in total and to avoid nerve injuries.

\section{Conclusion}

Brachial plexus lipomas are an extremely rare cause for TOS and are typically diagnosed several months delay after the initial symptoms. Microsurgical removal under permanent intraoperative electrophysiological monitoring should be the treatment of choice as it is safe and has a favorable outcome.

\section{Authors' Contributions}

O.G. contributed in writing the manuscript, acquisition of data, analysis and interpretation of data, study concept and design. Y.G. helped in revising the manuscript, analysis and interpretation of data. M.C. contributed in revising the manuscript, analysis and interpretation of data. T.F.D. helped in revising the manuscript, acquisition of data, analysis and interpretation of data. L.R. contributed in revising the manuscript, analysis and interpretation of data. D.P.in revising the manuscript, analysis and interpretation of data. R.J. in revising the manuscript, analysis and interpretation of data. U.S. in revising the manuscript, analysis and interpretation of data. K.H.W. in revising the manuscript, analysis and interpretation of data. A.-K.U. in writing the manuscript, acquisition of data, analysis and interpretation of data. All authors read and approved the final manuscript.

\section{Funding}

An IFORES grant (D/107-40960) to Oliver Gembruch from the University of Duisburg-Essen supported the research. The funders had no role in study design, data collection and analysis, decision to publish, or preparation of the manuscript.

\section{Conflict of Interest}

None declared.

\section{Acknowledgment}

The authors acknowledge support by the Open Access Publication Fund of the University of Duisburg-Essen.

\section{References}

1 Sanchez MR, Golomb FM, Moy JA, Potozkin JR. Giant lipoma: case report and review of the literature. J Am Acad Dermatol 1993;28 (2 Pt 1):266-268

2 Nakamura Y, Teramoto Y, Sato S, et al. Axillary giant lipoma: a report of two cases and published work review. J Dermatol 2014; 41(09):841-844

3 Rayan GM, Jensen C. Thoracic outlet syndrome: provocative examination maneuvers in a typical population. J Shoulder Elbow Surg 1995;4(02):113-117 
4 Sanders RJ, Hammond SL, Rao NM. Diagnosis of thoracic outlet syndrome. J Vasc Surg 2007;46(03):601-604

5 Moher D, Liberati A, Tetzlaff J, Altman DGPRISMA Group. Preferred Reporting Items for Systematic Reviews and Meta-Analyses: the PRISMA statement. Ann Intern Med 2009;151(04): 264-269, W64

6 Châtillon CE, Guiot MC, Jacques L. Lipomatous, vascular, and chondromatous benign tumors of the peripheral nerves: representative cases and review of the literature. Neurosurg Focus 2007;22(06):E18

7 Elia S, Cerioli A, Fiaschetti V, Granai AV. Infraclavicular subpectoral lipoma causing thoracic outlet syndrome. Int J Surg Case Rep 2015;9:101-104

8 Graf A, Yang K, King D, Dzwierzynski W, Sanger J, Hettinger P. Lipomas of the brachial plexus: a case series and review of the literature. Hand (N Y) 2019;14(03):333-338

9 Guha D, Kiehl TR, Guha A. Lipoma compressing the brachial plexus in a patient with sarcoidosis: case report. Br J Neurosurg 2011;25 (04):530-531

10 Kuyumdzhiev S, Wall ML, Rogoveanu R, Power D, Vohra R. Brachial plexus lipomata presenting with neurogenic and venous thoracic outlet syndrome: case reports and review of the literature. Ann Vasc Surg 2014;28(07):1797.e7-1797.e10

11 McKay G, Arlet V, Kern JA, Lau CL, Jones DR, Kozower BD. A bilobed thoracic outlet mass: options for resection. J Thorac Cardiovasc Surg 2009;137(01):245-247

12 Sergeant G, Gheysens O, Seynaeve P, Van Cauwelaert J, Ceuppens H. Neurovascular compression by a subpectoral lipoma. A case report of a rare cause of thoracic outlet syndrome. Acta Chir Belg 2003;103(05):528-531

13 Sul J, Lim J, Kang SK, Choi SW, Kwon HJ, Youm JY. Thoracic outlet syndrome induced by huge lipoma: a case report. Korean J Neurotrauma 2019;15(01):67-71

14 Vandeweyer E, Scagnol I. Axillary giant lipoma: a case report. Acta Chir Belg 2005;105(06):656-657

15 Mackinnon SE, Patterson GA, Novak CB. Thoracic outlet syndrome: a current overview. Semin Thorac Cardiovasc Surg 1996;8(02):176-182

16 Wojcik G, Sokolowska B, Piskorz J. Epidemiology and pathogenesis of thoracic outlet syndrome. Curr Issues Pharm Med Sci 2015;28 (01):24-26

17 Watson LA, Pizzari T, Balster S. Thoracic outlet syndrome part 1: clinical manifestations, differentiation and treatment pathways. Man Ther 2009;14(06):586-595

18 Weaver ML, Lum YW. New diagnostic and treatment modalities for neurogenic thoracic outlet syndrome. Diagnostics (Basel) 2017;7(02):E28

19 Rinehardt EK, Scarborough JE, Bennett KM. Current practice of thoracic outlet decompression surgery in the United States. J Vasc Surg 2017;66(03):858-865

20 Peek J, Vos CG, Ünlü Ç, van de Pavoordt HDWM, van den Akker PJ, de Vries JPM. Outcome of surgical treatment for thoracic outlet syndrome: systematic review and meta-analysis. Ann Vasc Surg 2017;40:303-326

21 Meson H. Lipoma in clinical dermatology. Clin Dermatol 1991;4:1-2

22 Di Benedetto G, Aquinati A, Astolfi M, Bertani A. Giant compressing lipoma of the thigh. Plast Reconstr Surg 2004;114(07): 1983-1985

23 Terzioglu A, Tuncali D, Yuksel A, Bingul F, Aslan G. Giant lipomas: a series of 12 consecutive cases and a giant liposarcoma of the thigh. Dermatol Surg 2004;30(03):463-467

24 Bolognia JL, Jorizzo JL, Schaffer JV, (eds). Dermatology, 3rd ed. New York: Elsevier; 2012:2525-2535

25 Copcu E, Sivrioglu NS. Posttraumatic lipoma: analysis of 10 cases and explanation of possible mechanisms. Dermatol Surg 2003;29 (03):215-220

26 Meggitt BF, Wilson JN. The battered buttock syndrome-fat fractures. A report on a group of traumatic lipomata. Br J Surg 1972;59 (03):165-169

27 Aust MC, Spies M, Kall S, et al. Lipomas after blunt soft tissue trauma: are they real? Analysis of 31 cases. Br J Dermatol 2007; 157(01):92-99

28 Allen B, Rader C, Babigian A. Giant lipomas of the upper extremity Can J Plast Surg 2007;15(03):141-144

29 Kim DH, Murovic JA, Tiel RL, Moes G, Kline DG. A series of 397 peripheral neural sheath tumors: 30 -year experience at Louisiana State University Health Sciences Center. J Neurosurg 2005;102 (02):246-255

30 Knight DM, Birch R, Pringle J. Benign solitary schwannomas: a review of 234 cases. J Bone Joint Surg Br 2007;89(03):382-387

31 Wiesmann M, Linn J, Brückmann H. Atlas klinische Neuroradiologie: Wirbelsäule und Spinalkanal. Berlin, Heidelberg: Springer; 2014:244-245

32 Novak CB, Collins ED, Mackinnon SE. Outcome following conservative management of thoracic outlet syndrome. J Hand Surg Am 1995;20(04):542-548

33 Born G. Gigantic lipomas. Plast Reconstr Surg 1995;96(07): 1750-1751

34 Nichter LS, Gupta BR. Liposuction of giant lipoma. Ann Plast Surg 1990;24(04):362-365

35 Rubenstein R, Roenigk HH Jr, Garden JM, Goldberg NS, Pinski JB. Liposuction for lipomas. J Dermatol Surg Oncol 1985;11(11): 1070-1074

36 Sakai Y, Okazaki M, Kobayashi S, Ohmori K. Endoscopic excision of large capsulated lipomas. Br J Plast Surg 1996;49(04):228-232

37 Kamble N, Shukla D, Bhat D. Peripheral nerve injuries: electrophysiology for the neurosurgeon. Neurol India 2019;67(06): 1419-1422

38 Scibilia A, Terranova C, Rizzo V, et al. Intraoperative neurophysiological mapping and monitoring in spinal tumor surgery: sirens or indispensable tools? Neurosurg Focus 2016;41(02):E18

39 Flores LP. The importance of the preoperative clinical parameters and the intraoperative electrophysiological monitoring in brachial plexus surgery. Arq Neuropsiquiatr 2011;69(04):654-659 